2018-05

Spatiotemporal variations in vegetation cover on the Loess Plateau, China, between 1982 and 2013: possible causes and potential impacts

\author{
Kong, D
}

http://hdl.handle.net/10026.1/17696

10.1007/s11356-018-1480-x

Environmental Science and Pollution Research

Springer Science and Business Media LLC

All content in PEARL is protected by copyright law. Author manuscripts are made available in accordance with publisher policies. Please cite only the published version using the details provided on the item record or document. In the absence of an open licence (e.g. Creative Commons), permissions for further reuse of content should be sought from the publisher or author. 


\title{
Spatiotemporal variations in vegetation cover on the Loess Plateau, China, between 1982 and 2013: possible causes and potential impacts
}

\author{
Dongxian Kong ${ }^{1} \cdot$ Chiyuan Miao $^{1}$ (D) Alistair G. L. Borthwick ${ }^{2} \cdot$ Xiaohui Lei $^{3} \cdot \mathrm{Hu} \mathrm{Li}^{4}$
}

Received: 30 October 2017 / Accepted: 4 February 2018

(C) Springer-Verlag GmbH Germany, part of Springer Nature 2018

\begin{abstract}
Vegetation is a key component of the ecosystem and plays an important role in water retention and resistance to soil erosion. In this study, we used a multiyear normalized difference vegetation index (NDVI) dataset (1982-2013) and corresponding datasets for observed climatic variables to analyze changes in the NDVI at both temporal and spatial scales. The relationships between NDVI, climate change, and human activities were also investigated. The annual average NDVI showed an upward trend over the 32-year study period, especially in the center of the Loess Plateau. NDVI variations lagged behind monthly temperature changes by approximately 1 month. The contribution of human activities to variations in NDVI has become increasingly significant in recent years, with human activities responsible for 30.4\% of the change in NDVI during the period 2001-2013. The increased vegetation coverage has reduced soil erosion on the Loess Plateau in recent years. It is suggested that natural restoration of vegetation is the most effective measure for control of erosion; engineering measures that promote this should feature in the future governance of the Loess Plateau.
\end{abstract}

Keywords Vegetation cover $\cdot$ Loess Plateau $\cdot$ Soil erosion $\cdot$ Climate change $\cdot$ Human activities

\section{Introduction}

Vegetation connects the soil, water, and atmosphere and is an important indicator of changes in climate and human activities

Responsible editor: Philippe Garrigues

Electronic supplementary material The online version of this article (https://doi.org/10.1007/s11356-018-1480-x) contains supplementary material, which is available to authorized users.

Chiyuan Miao

miaocy@vip.sina.com

1 State Key Laboratory of Earth Surface Processes and Resource Ecology, Faculty of Geographical Science, Beijing Normal University, Beijing 100875, China

2 School of Engineering, The University of Edinburgh, The King's Buildings, Edinburgh EH9 3JL, UK

3 State Key Laboratory of Simulation and Regulation of Water Cycle in River Basin, China Institute of Water Resources and Hydropower Research, Beijing 100038, China

4 Key Laboratory of Agricultural Non-Point Source Pollution Control, Ministry of Agriculture/Institute of Agricultural Resources and Regional Planning, Chinese Academy of Agricultural Sciences, Beijing 100081, China
(Vereecken et al. 2010). In an ecosystem, the ground cover provided by vegetation plays a pivotal role in the regulation of various biogeochemical cycles, e.g., water (Gerten et al. 2004; Scheffer et al. 2005; Troch et al. 2009) and carbon dioxide (Allen et al. 1987; Levis et al. 2000). At the macroscale, landatmosphere exchanges of energy and water result in positive feedback between vegetation density and climate, especially in semi-arid zones (Dekker et al. 2007; Zeng et al. 1999). Variations in vegetation growth due to either human activities or climate change can induce natural disturbances. Undoubtedly, changes in vegetation directly or indirectly modify biosphere-atmosphere interactions, including the hydrological cycle (Gao et al. 2016; Liang et al. 2015; Wu et al. 2017) and energy budgets (Chapin et al. 2005; McVicar et al. 2007). A lack of protective vegetation can easily trigger severe erosion (Cantón et al. 2001; Ludwig et al. 2005) and subsequent deterioration of the soil (Marques et al. 2008), decline in land productivity (Lantican et al. 2003; Pimentel and Kounang 1998), and degradation of streams, lakes, and estuaries by transported sediments and pollutants (Ouyang et al. 2010; Ouyang et al. 2009; Tang et al. 2011; Zhang et al. 2008). Moreover, changes in vegetation cover are known to influence the climate system by modifying the radiative, momentum, and hydrologic balance of the land surface (Levis et al. 2000). 
The Loess Plateau covers an area of more than $620,000 \mathrm{~km}^{2}$ over the middle reaches of the Yellow River in northern China (Fig. 1). Highly erodible soils, steep slopes, heavy storms, and low levels of vegetation cover from intensive cultivation and improper land use have led to the Loess Plateau becoming one of the most highly eroded regions in the world ( $\mathrm{Li}$ et al. 2010). With a mean denudation rate of $3.0 \pm$ $1.2 \mathrm{~mm}$ year $^{-1}$ (Yue et al. 2016), the Loess Plateau supplies $90 \%$ of the sediment in the Yellow River, leading to the wellknown "hanging river" phenomenon in the lower reaches (Kong et al. 2015; Tang et al. 1991). For example, at Kaifeng in Henan Province, the Yellow River is approximately $10 \mathrm{~m}$ above ground level (Miao et al. 2016). The climate on the Loess Plateau is arid and semi-arid, meaning that climate change, and especially changes in precipitation, has a direct influence on vegetation cover (Li et al. 2012; Liu and Sang 2013; Zhang et al. 2012a, b). Temperature has been reported to be the controlling factor for seasonal changes in vegetation growth on the Loess Plateau (Xin et al. 2008). Sun et al. (2015) reported that higher temperatures promote the growth of vegetation in areas that are less water-stressed. The relationship between vegetation and precipitation on the plateau has been studied extensively (Wang et al. 2010a). In addition to climate change, human activity is an important factor that can influence vegetation growth. To mitigate serious soil erosion, a series of programs to control water and soil loss have been implemented on the plateau since the 1980s, including optimizing the structure and configuration of land usages, terracing the slopes, restoring sloping cropland to forests and grassland, enclosing the hillsides and banning grazing, and building reservoirs (Fan et al. 2015a; Fan et al. 2015b; Miao et al. 2011; Wang et al. 2015; Yang 2003). By 2006, about 49\% of eroded land was subject to these types of soil and water conservation measures (including $52,729 \mathrm{~km}^{2}$ of prime farmland, $94,613 \mathrm{~km}^{2}$ of afforestation, and $34,938 \mathrm{~km}^{2}$ of grass planting) (Gao et al. 2011). Undoubtedly, these human activities have played a significant role in the improvements in vegetation coverage. However, regional urbanization and industrialization, overgrazing, logging, and excessive reclamation and mining have resulted in adverse effects on vegetation growth on the Loess Plateau because of their unsustainable use of water resources (Feng et al. 2016). It has been reported that human activities have played a major role in land use changes on the Loess Plateau, but that the change in vegetation growth has probably been accelerated by climate change ( $\mathrm{Li}$ et al. 2016). Thus, the overall impact of human activities remains to be fully assessed. Although many previous studies have considered the impact of climate change and human activities on vegetation cover and ecological restoration on the Loess Plateau (Yi et al. 2014; Li et al. 2013; Xin et al. 2008), the

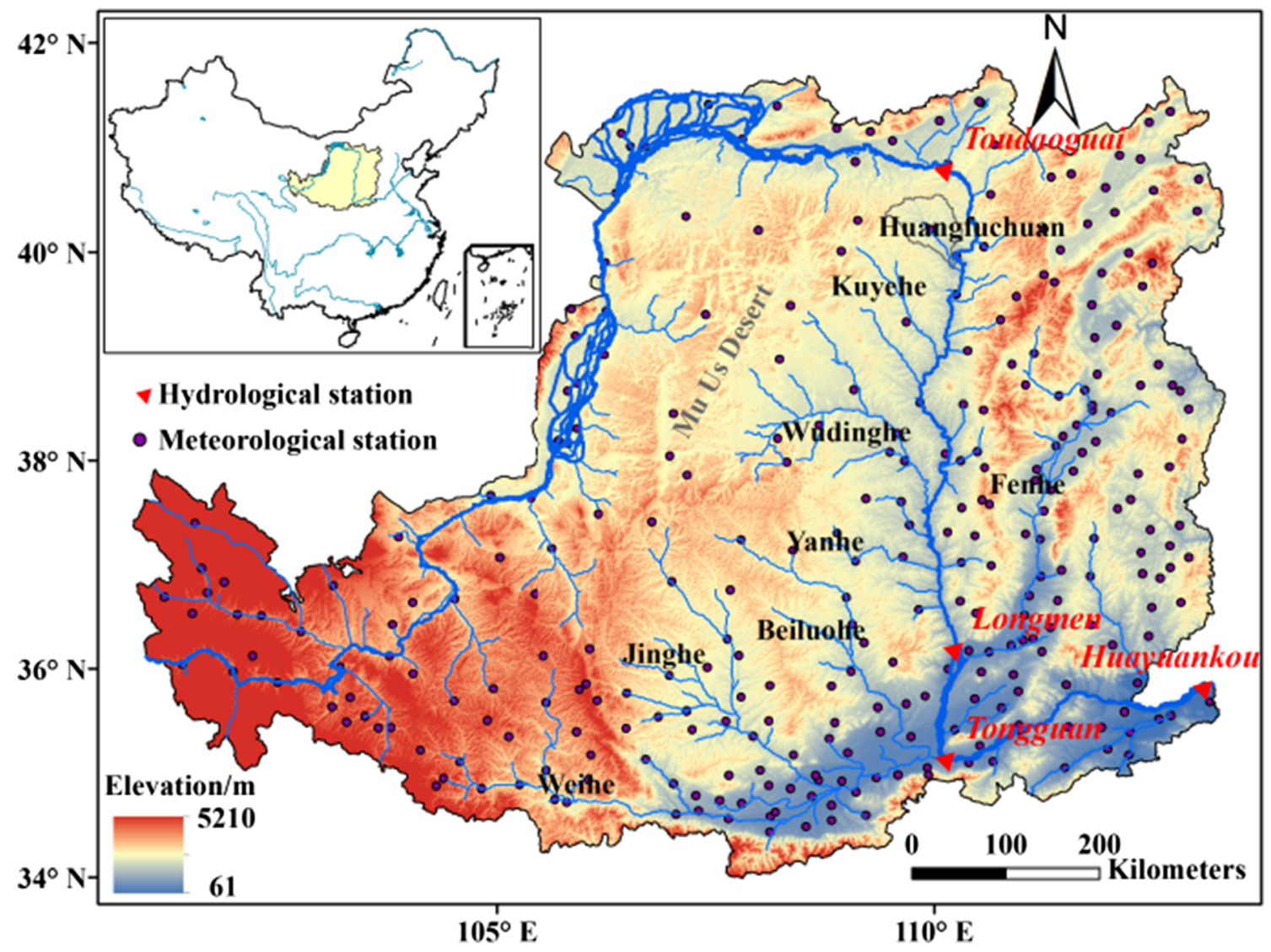

Fig. 1 Location of the Loess Plateau and the distribution of meteorological stations 
majority focused on purely qualitative evaluation of the effects of climate change or human activities on variations in the normalized difference vegetation index (NDVI) and did not take into account time-lag effects.

With this in mind, the present study aims to provide a quantitative overview of vegetation cover on the Loess Plateau that can be used to guide future studies on ecological rehabilitation in this region. The study has the following objectives: (i) to analyze variations in vegetation cover on the Loess Plateau using NDVI time series data, (ii) to investigate time-lag effects of the vegetation response to climate factors, and (iii) to quantify contributions from climate change and human activities to changes in vegetation cover.

\section{Datasets and methods}

\section{Data sources}

The NDVI, defined as the ratio of the difference between nearinfrared and red visible reflectance to their sum, is an indicator of vegetation greenness and productivity. The NDVI has been widely used to describe vegetation dynamics because of its close correlation with biophysical and biochemical variables, such as vegetation coverage (Sun et al. 2015; Zhang et al. 2016). In this study, we used the long time series NDVI dataset from the Global Inventory Monitoring and Modeling Systems (GIMMS3g) for the period from January 1982 to December 2013, which we acquired from the National Oceanographic and Atmospheric Administration (NOAA) (http://ecocast.arc.nasa.gov/data/pub/gimms) (Tucker et al. 2005). Data were collected at 15-day intervals at a spatial resolution of $0.083^{\circ}$ (Fensholt and Proud 2012). Sun et al. (2015) compared the monthly NDVI series trends on the Loess Plateau from LTDR (AVH13C1) (1995 to 1999) and MODIS (MOD13A3) (2000 to 2005) with the corresponding GIMMS dataset (1995 to 2005). The results indicated that GIMMS NDVI systematically underestimates vegetation on the Loess Plateau (by up to 0.05). The regression slope of the LTDR NDVI versus the GIMMS NDVI was very similar to that of the MODIS NDVI versus the GIMMS NDVI. In order to improve the accuracy and reliability of the dataset, we used the widely accepted MODIS dataset from February 2000 to December 2013 to correct the GIMMS3g dataset. First, we used linear regression to assess the relationship between the GIMMS3g and MODIS datasets using data from February 2000 to December 2013 for each grid point in the two datasets. Then, we reconstructed all the data for each grid point over the period from January 1982 to December 2013. This correction method has been used in other previous studies (e.g., Zhang et al. 2016; Li et al. 2017). Both the GIMMS3g and MODIS NDVI composites were created with the maximum value composite (MVC) technique, which minimizes the effects of cloud cover by selecting the highest NDVI at each pixel from daily images taken over a period of 15 or 16 days (Holben 1986). The seasonal mean NDVI values were averaged and grouped by season as follows: spring (March to May), summer (June to August), autumn (September to November), and winter (December to February of the next year) (Sun et al. 2015).

The observed monthly precipitation and temperature datasets used in this study were provided by the National Meteorological Information Center of the China Meteorological Administration (http://data.cma.cn). The sitebased datasets for precipitation and temperature were constructed from approximately 2400 station observations across China, including 299 stations on the Loess Plateau (Fig. 1). This high-density dataset ensures the reliability of our analysis. For consistency with the NDVI data, we used linear interpolation to transform the precipitation and temperature data to a $0.083^{\circ} \times 0.083^{\circ}$ grid for the period 1982-2013 .

Two detailed national soil erosion surveys were undertaken in China during the periods 1995-1996 and 2010-2012. The soil erosion data were obtained from http://cese.pku.edu.cn/ chinaerosion provided by Yue et al. (2016). The national soil erosion survey was conducted with a county as a unit survey area and included a total of 348 counties across the Loess Plateau.

\section{Methodology}

\section{(1) Trend detection}

The statistical significance of the trends in NDVI, precipitation, and temperature was tested with the nonparametric Mann-Kendall test (Mann 1945), and the trend magnitudes were computed by Sen's slope estimator (Sen 1968). The rank-based non-parametric MannKendall test is encountered more frequently than parametric statistical tests in analyses of hydrometeorological time series (Yue et al. 2002) and makes no assumptions about the probability distribution (Önöz and Bayazit 2003). This method can examine trends in a time series without requiring normality or linearity. The mutation analysis was conducted with a sequential Mann-Kendall test, which is sequential progressive $(U(t))$ and backward $\left(U^{\prime}(t)\right)$ analyses based on the Mann-Kendall test. If the two series cross and then diverge from each other for a long period of time, the initial divergence year marks an abrupt turning point in the trend (Mohsin and Gough 2010; Tabari et al. 2011). The sequential behavior fluctuates close to zero. A detailed description of the MannKendall and sequential Mann-Kendall tests can be found in previous literature (Partal and Kahya 2006; Sayemuzzaman et al. 2014). 


\section{(2) Time-lag detection}

The relationship between the NDVI and the climatic factors is shown in Eq. (1):

$Z=k_{i} \times V+b$

where $k_{i}$ is the regression coefficient with a time lag of $i$ months, $Z$ is the NDVI time series (1982-2013), and $V$ is the time series for precipitation or temperature, with a time lag of $i$. For each climatic factor, the lag month $(i)$ that has the highest coefficient of determination $\left(R^{2}\right)$ is the best time lag for the vegetation response to that climatic factor.

\section{(3) Quantitative assessment of the changes in NDVI due to climate change and human activities}

Briefly, variations in the NDVI are the result of both climate change and human activities. Assuming that the effects of climate change and human activities on NDVI are independent, the total change in NDVI $\left(\Delta N D V I_{\text {total }}\right)$ can be expressed as

$\Delta N D V I_{\text {total }}=\Delta N D V I_{\text {climate }}+\Delta N D V I_{\text {human }}$

where $\Delta N D V I_{\text {climate }}$ represents the change in NDVI caused by climate change and $\triangle N D V I_{\text {human }}$ represents the change in NDVI caused by human activities.

To quantify the influence of climate change and human activities on NDVI variations, a baseline (benchmark) period is set. Usually, a period during which one individual factor dominates the impact is selected as the baseline period. Here, climate change dominated the impact during the baseline period, with a negligible effect of human activities $(\mathrm{Wu}$ et al. 2017). The relationship between NDVI and climate factors during the baseline period is determined by multiple linear regression.

Then, the NDVI during the post-baseline period can be reconstructed on the basis of the above multiple linear regression. The variation in the reconstructed NDVI is only affected by climate change. According to Eq. (2), any differences between the observed and reconstructed NDVI can be attributed to human activities. Thus, the contributions of climate change $\left(C_{\text {climate }}\right)$ and human activities $\left(C_{\text {human }}\right)$ to variations in NDVI can be calculated by

$C_{\text {climate }}=\frac{x_{\text {reconstruction }}-x_{\text {baseline }}}{x_{\text {observation }}-x_{\text {baseline }}} \times 100 \%$

$C_{\text {human }}=100 \%-C_{\text {climate }}$

where $x_{\text {observation }}$ represents the mean annual observed NDVI during the post-baseline period, $x_{\text {reconstruction }}$ represents the mean reconstructed annual NDVI during the post-baseline period, and $x_{\text {baseline }}$ represents the mean annual NDVI during the baseline period. The calculated contributions to changes in vegetation cover dynamics from climate change and human activities are not absolute but instead are calculated relative to this baseline period. This process is shown schematically in Fig. 2. We have used a similar application of this method in our previous studies (Kong et al. 2016; Miao et al. 2011).

\section{Results}

\section{Temporal variations in vegetation cover}

The magnitude of the monthly NDVI and how it changes over time are important indicators of the contribution of vegetation activity in different months to the total annual plant growth. Figure 3 shows the temporal variations in the average NDVI for the Loess Plateau for the period 1982-2013. The NDVI fluctuated seasonally, with the highest values occurring between July and August and the lowest values occurring between January and February, indicating that the vegetation cover is dependent on the climate. Both annual and seasonal NDVI largely improved from 1982 to 2013, especially in the most recent decade. There was a significant upward trend in the annual average NDVI over the 32-year study period (Table $1 ; Z=3.91$ ). Autumn showed the most obvious increase $(Z=3.78)$, with a rate of 0.0013 NDVI units per year, followed by spring $(Z=2.64)$ and summer $(Z=2.06)$. However, the NDVI values showed rapid growth in summer during recent decades (Fig. 3). It is noteworthy that the monthly NDVI variation trends were not consistent, as can be seen in Table 1. For January-March, the monthly NDVI trends were negative but had non-significant $Z$ values in the MannKendall test. This may be related to the coupling of the negative effects of afforestation with the decreased rainfall in the winter in the early 2000s (or increased evaporation due to global warming), especially in the Huangfuchuan, Kuyehe,

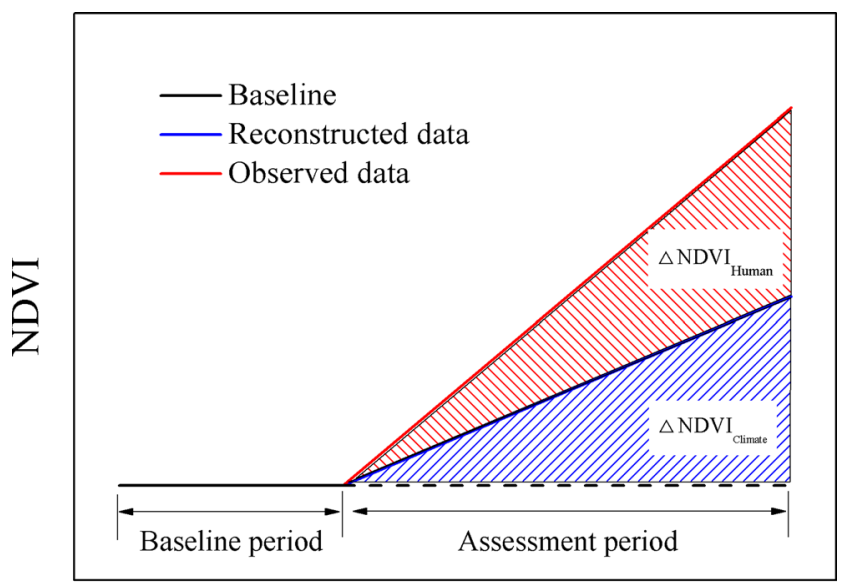

Time

Fig. 2 Schematic diagram illustrating quantitative assessment of the impact of climate change and human activities on NDVI 


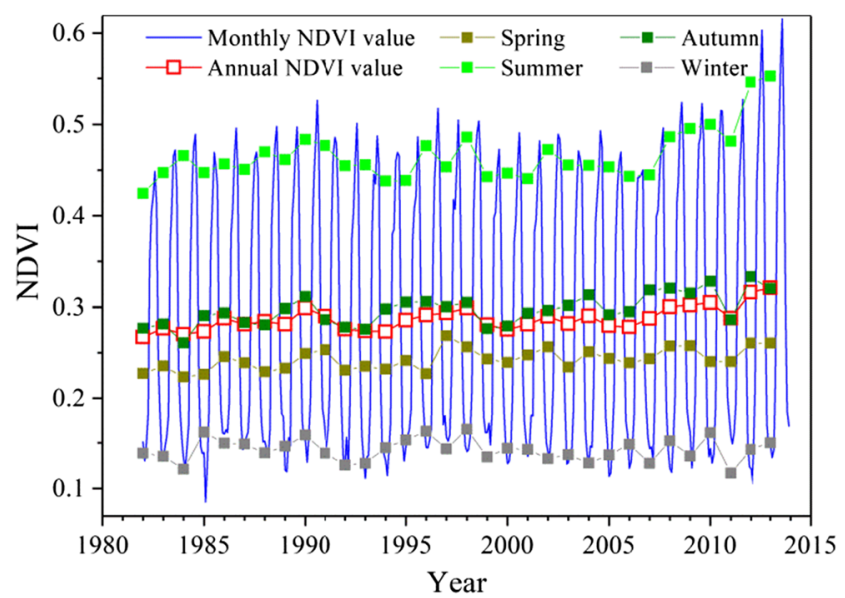

Fig. 3 Temporal variations in the average NDVI for the Loess Plateau during the period 1982-2013

Wudinghe, and Yanhe watersheds (Fu et al. 2017; Sun et al. 2015). For April-October, there were significant upward trends in the NDVI. The peak increase was in October, with a rate of 0.002 NDVI units per year.

\section{Spatial variations in vegetation cover}

Owing to the complex climate on the Loess Plateau, vegetation cover follows a gradient across the plateau. Figure 4 shows the spatial variations in the average NDVI during the period 1982-2013. Vegetation cover is greater in the southeast of the plateau than in the northwest. The 0.3 NDVI contour (blue) did not change significantly between 1982 and 2013. However, the 0.2 NDVI contour (red) clearly retreated toward the northwest in 2001-2013, compared with the previous time period. This indicates that the vegetation cover in the center of the Loess Plateau changed dramatically, as shown in detail in Fig. 5. Although there was an overall upward trend in the annual average NDVI at the level of the study area as a whole, there was in fact a high degree of spatial heterogeneity. As shown in Fig. 5, the NDVI tended to increase in most areas, especially in the center of the plateau, but decreased sharply in the marginal areas in the west of the plateau. The center of the plateau contains highly eroded areas termed "hilly and gully regions," which have been the focus of vegetation restoration efforts in the "Grain-to-Green" project over the last 10 years (Sun et al. 2015). This project is largely responsible for the recovery of vegetation in the center of the plateau over the last decade. Figure S1 shows the changes in land use on the Loess Plateau over the past three decades. It can be seen that residential land use increased in the marginal areas of the plateau, which likely explains the downward NDVI trends in these regions.

\section{Impact of climate change on vegetation coverage}

The results of the Mann-Kendall test for trends in precipitation and temperature on the Loess Plateau are summarized in Table 1, and the temporal variations in annual precipitation and average temperature over the period 1982-2013 are shown in Fig. S2. Precipitation increased in some months and decreased in other months, and overall, there was a nonsignificant upward trend $\left(0.4603 \mathrm{~mm}\right.$ year $\left.^{-1}\right)$ in annual precipitation over the study period (1982-2013). We observed an
Table 1 Results of the MannKendall test for NDVI, precipitation, and temperature. Ital emphasis indicates that the trend was significant at the $95 \%$ confidence level

\begin{tabular}{|c|c|c|c|c|c|c|}
\hline \multirow[t]{2}{*}{ Time } & \multicolumn{2}{|l|}{ NDVI } & \multicolumn{2}{|c|}{ Precipitation } & \multicolumn{2}{|c|}{ Temperature } \\
\hline & $Z$ & Slope & $Z$ & Slope $\left(m m\right.$ year $\left.^{-1}\right)$ & $Z$ & Slope $\left({ }^{\circ} \mathrm{C}\right.$ year $\left.{ }^{-1}\right)$ \\
\hline January & -0.83 & -0.0002 & 0.47 & 0.0244 & 0.24 & 0.0055 \\
\hline February & -0.86 & -0.0002 & 1.54 & 0.0767 & 2.51 & 0.1040 \\
\hline March & -0.44 & -0.0001 & -1.70 & -0.2591 & 3.03 & 0.0966 \\
\hline April & 2.55 & 0.0007 & -0.47 & -0.0842 & 2.40 & 0.0609 \\
\hline May & 3.13 & 0.0009 & -0.08 & -0.0687 & 1.86 & 0.0334 \\
\hline June & 2.32 & 0.0010 & -0.83 & -0.3322 & 4.10 & 0.0624 \\
\hline July & 1.96 & 0.0009 & 0.83 & 0.3447 & 2.77 & 0.0427 \\
\hline August & 2.68 & 0.0011 & -0.76 & -0.3404 & 2.77 & 0.0400 \\
\hline September & 3.36 & 0.0012 & 1.86 & 0.9025 & 1.12 & 0.0247 \\
\hline October & 4.01 & 0.0019 & -0.76 & -0.1829 & 1.25 & 0.0236 \\
\hline November & 1.05 & 0.0002 & 0.37 & 0.0365 & 1.51 & 0.0402 \\
\hline December & 0.18 & 0.0000 & 0.00 & -0.0003 & 0.34 & 0.0092 \\
\hline Spring & 2.64 & 0.0006 & -0.70 & -0.3285 & 3.71 & 0.0669 \\
\hline Summer & 2.03 & 0.0011 & 0.24 & 0.2704 & 3.49 & 0.0489 \\
\hline Autumn & 3.78 & 0.0013 & 1.64 & 0.7349 & 2.03 & 0.0287 \\
\hline Winter & -0.42 & 0.0000 & 0.73 & 0.0960 & 1.70 & 0.0468 \\
\hline Annual & 3.91 & 0.0007 & 0.37 & 0.4603 & 3.36 & 0.0440 \\
\hline
\end{tabular}



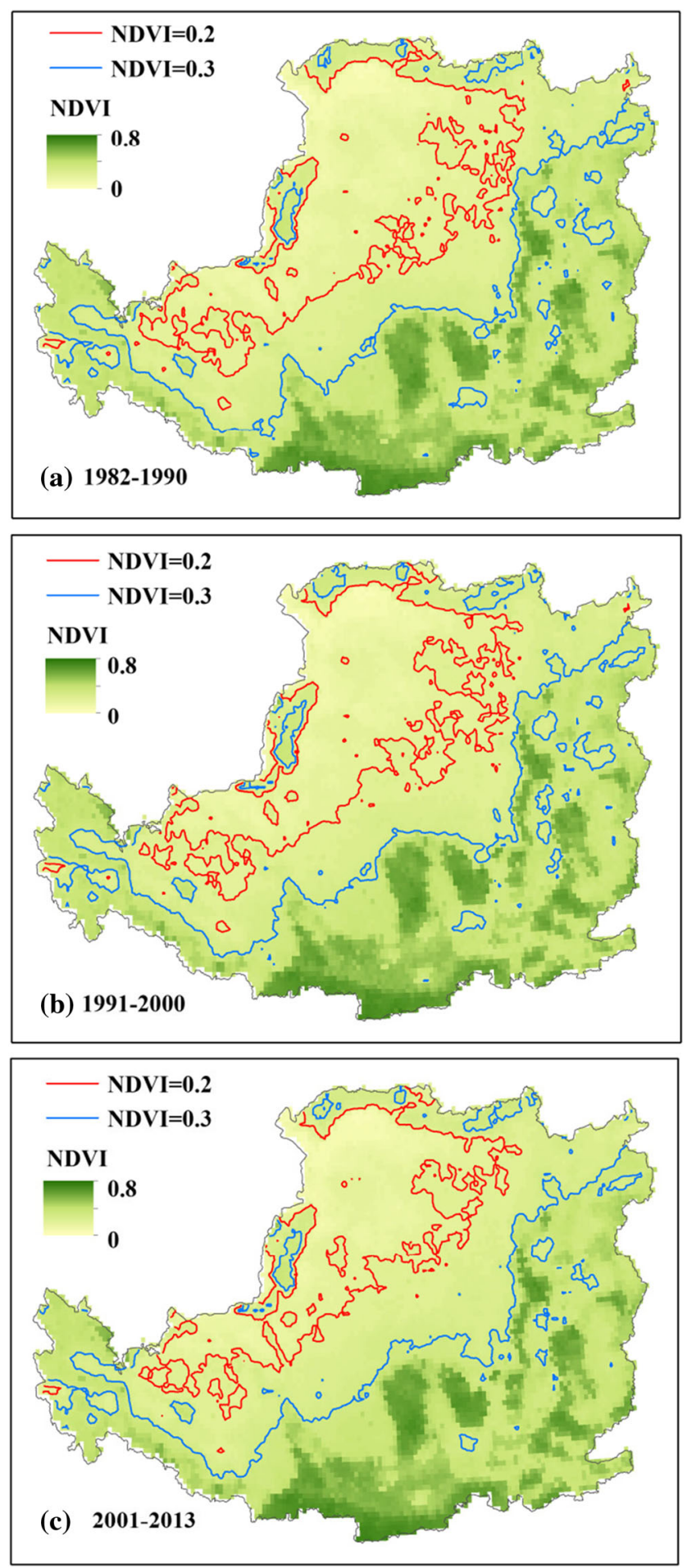

Fig. 4 Spatial distribution of the average NDVI for the Loess Plateau. a 1982-1990. b 1991-2000. c 2001-2007. d 2008-2013

upward trend in temperature in all months (Table 1), with an annual rate of increase of $0.0440{ }^{\circ} \mathrm{C}_{\text {year }}{ }^{-1}$, which was significant at the $95 \%$ confidence level. The concurrent increases in summer rainfall and temperature could enhance plant growth on the plateau.
It is likely that the trends and patterns in the NDVI are coupled to trends and patterns in climatic variables. We found that the pattern of mean monthly precipitation and temperature values was consistent with changes in NDVI: high values in summer and low values in winter (Fig. 6). It can be seen in Fig. $6 \mathrm{c}$ that there was a steep increase in NDVI from April to May and a steep decrease from September to October. Notably, the greatest mean precipitation occurred in July, but the largest mean NDVI occurred in August. This indicates that there is a time lag in the NDVI response to climate factors. Such a time-lag effect has been reported in previous studies (Wu et al. 2015). In the present study, we investigated the scale of this time lag.

To evaluate the dependency of the vegetation on temperature and precipitation at different time lags, the temperature and precipitation data were designated as independent variables and the NDVI data as the dependent variable. Previous studies at the monthly scale found that the time lag of vegetation responses to climate was generally shorter than 3 months (Anderson et al. 2010; Chen et al. 2014). Therefore, we considered time lags in the range 0-3 months.

The time lags between NDVI and temperature or precipitation are shown in Fig. 7. We found that the time lags of the NDVI response to climatic factors fell within 1 month. The results verified our hypothesis that the time lag of the vegetation response may be different for different climatic factors. Vegetation growth showed the greatest correlation with precipitation within the same month and exhibited no lag effects over most of the plateau. Grid locations with a 0 -month time lag accounted for $66.1 \%$ of the entire study region, and the remaining grid locations had a 1-month time lag. For temperature, grid locations with a 0 -month time lag accounted for $36.1 \%$ of the study region, with 1-month time lags occurring in $63.9 \%$ of the region. As shown in Fig. 7, the time lags between NDVI and the climatic factors were different in different regions of the plateau. This may be due to differences in vegetation, as reported previously (Wu et al. 2015).

\section{Impact of human activities on vegetation coverage}

Soil conservation projects on the Loess Plateau have paid great attention to re-vegetation. Planting of trees and grasses was the major re-vegetation method used until the late 1990s, but most of the planting attempts were not successful. The planted trees and grasses grew well over the first few years but then began to die because of the formation of a dry layer in the soil (Zhou et al. 2013). This means that climate change dominated NDVI variations during that period, with only a negligible influence of human activities. Thus, in this study, we used that period (1982-1990) as our baseline period. In the present research, therefore, we compared the different contributions of climate change and human activities to variations in NDVI with respect to this baseline period. In this work, we 
Fig. 5 Spatiotemporal changes in the annual average NDVI on the Loess Plateau during the period 1982-2013

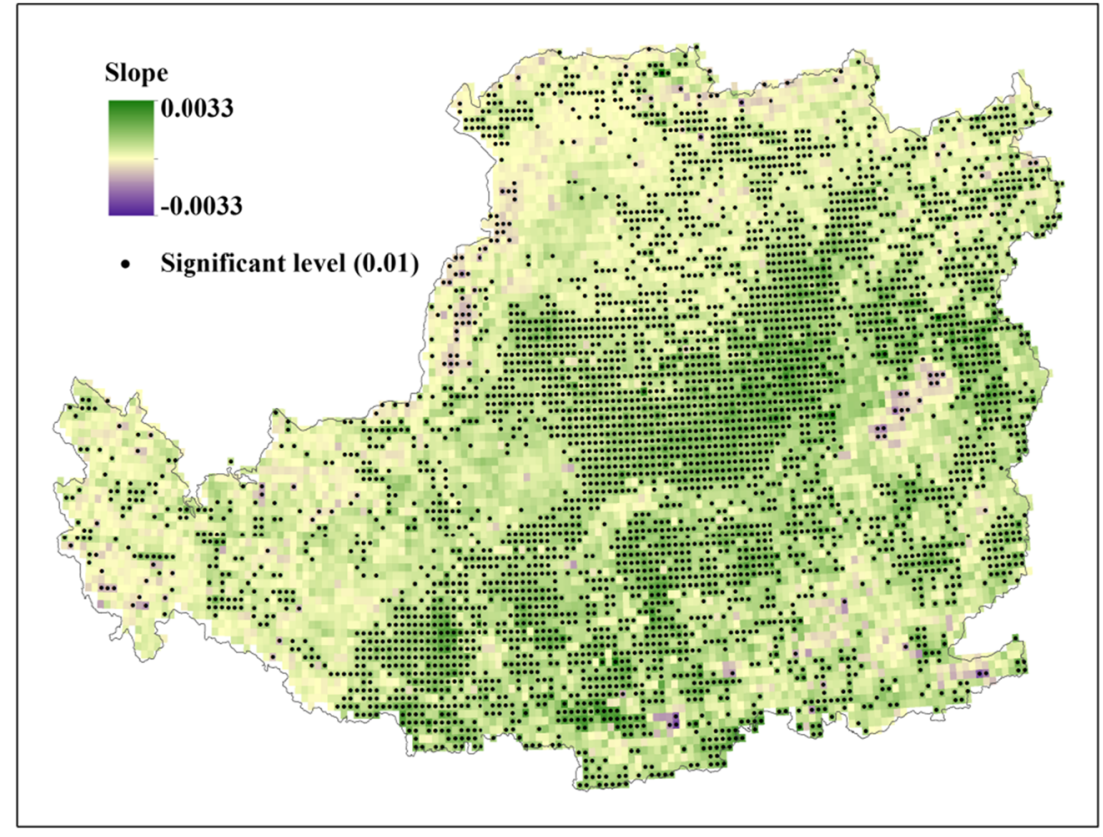

first detected time-lag effects, and then adjusted the data series on the basis of the obtained time-lag scale, and then performed the quantitative calculation.

Because the dependence of vegetation on climate factors varies between the growing season (May to September) and the non-growing season (October to April), we explored the relationships separately for the separate seasons. Multiple linear regression was used to simulate the relationship between NDVI and the climate factors, and then, the model was used to

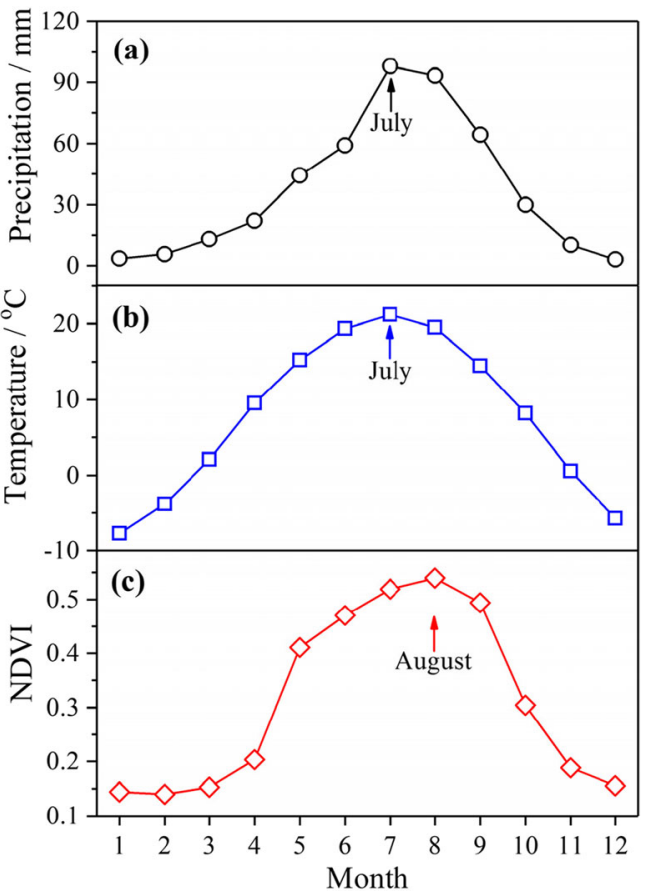

Fig. 6 Comparison of average monthly precipitation (a), temperature (b), and NDVI (c) on the Loess Plateau over the period 1982-2013 make predictions. First, we verified in IBM SPSS Statistics 20 that the data met the preconditions for multiple linear regression. The linear relationships between NDVI and precipitation/temperature were detected via simple linear regression, and there was no multicollinearity between precipitation and temperature (variance inflation factors $<3$ ). We detected no autocorrelation in the NDVI data series (Durbin Watson $\approx 2$ ). Second, after fitting the regression model, the residuals were checked and found to fit the normal distribution. The relationships between NDVI and the climate factors in the baseline period during the growing season and the nongrowing season are presented in Fig. S3 and demonstrate that our multiple linear regression models were acceptable $[R$ square values of 0.91 (growing season) and 0.84 (non-growing season), with $P$ values less than 0.01$]$. The positive coefficients between the NDVI and precipitation (temperature) suggest that increasing precipitation (temperature) led to an improvement in vegetation cover under certain conditions. The annual NDVI data series for the period 1991-2013 was reconstructed on the basis of these two models. The quantitative results are summarized in Table S1. During the period 1991-2013, the contribution of climate change to variations in NDVI was $75.4 \%$, higher than the contribution from human activities (24.6\%). However, during the period 1991-2000, climate change played a highly dominant role, with a contribution of $97.3 \%$. For the period 2001-2013, the overall contribution from human activities increased significantly to $30.4 \%$ while the contribution from climate change decreased to $69.6 \%$. This is consistent with previous studies indicating that soil conservation projects that included re-vegetation were effective from the late 1990s (Zhou et al. 2013; Li et al. 2016). Our results indicate that human activities have had a 


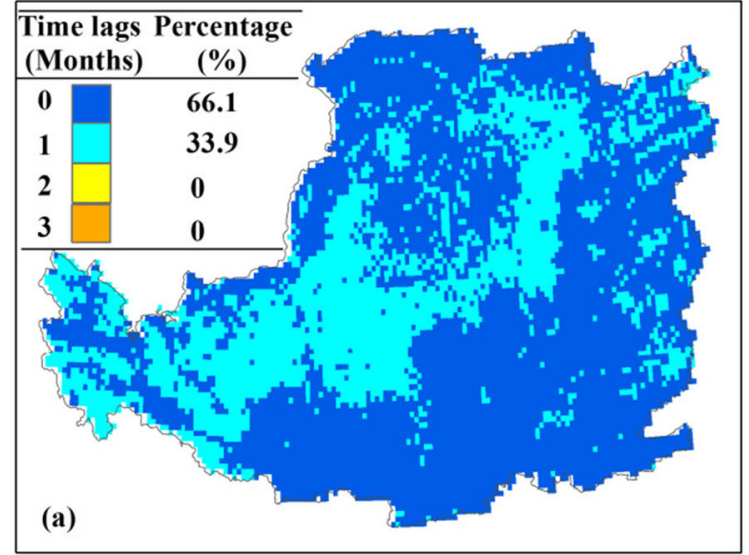

Fig. 7 Time lags between NDVI and precipitation (a) and temperature (b)

net positive impact on the restoration of vegetation on the Loess Plateau, in line with previous results (Yi et al. 2014).

\section{Influence of vegetation cover on soil retention}

The Loess Plateau is famous for its deep loess deposits. Because of the individual geographic landscape, the soil, the climatic conditions, and the long history of human activity stretching over 5000 years, the plateau has suffered from intensive soil erosion, which has had prolonged effects on social and economic development in the region (Shi and Shao 2000). Vegetation is one of the key factors affecting soil erosion, and restoration of vegetation is a dominant factor in reducing soil erosion (Xin et al. 2011; Xin et al. 2012; Zheng 2006; Zhou et al. 2006). Relatively high degrees of vegetation cover are found in the mountainous areas and the agricultural areas (the valley plain) in the southern region of the plateau (e.g., the Weihe and Fenhe plains). Less-dense vegetation is found in the loess hilly and gully regions, which have been subject to severe soil erosion (e.g., the Mu Us Desert) (Fig. 4). Restoration of vegetation has mainly occurred in areas of the plateau dominated by water erosion; therefore, we did not consider wind erosion in this assessment (Fu et al. 2011). According to the second national soil erosion survey, over $25.7 \%$ of the Loess Plateau suffers from water erosion of the soil to a moderate or higher degree.

Figure 8 shows the spatial distribution of water erosion on the Loess Plateau according to national surveys conducted in 1995-1996 and 2010-2012. All regions on the plateau have suffered from water erosion to varying degrees. Figure 8a shows that the area with the most severe soil erosion (greater than $8 \mathrm{Mt}$ year $^{-1}$ ) lies in the section between the Toudaoguai and Longmen stations (Zhao et al. 2016), which is also called the "Coarse Sandy Hilly Catchments" area (Zhang et al. 2008). This region covers an area of $7.86 \times 10^{4} \mathrm{~km}^{2}$, accounting for only $14.8 \%$ of the entire Yellow River basin but producing nearly $80 \%$ of the coarse sediment input to the Yellow River (Xu et al. 1998). A comparison of the two periods (Fig.

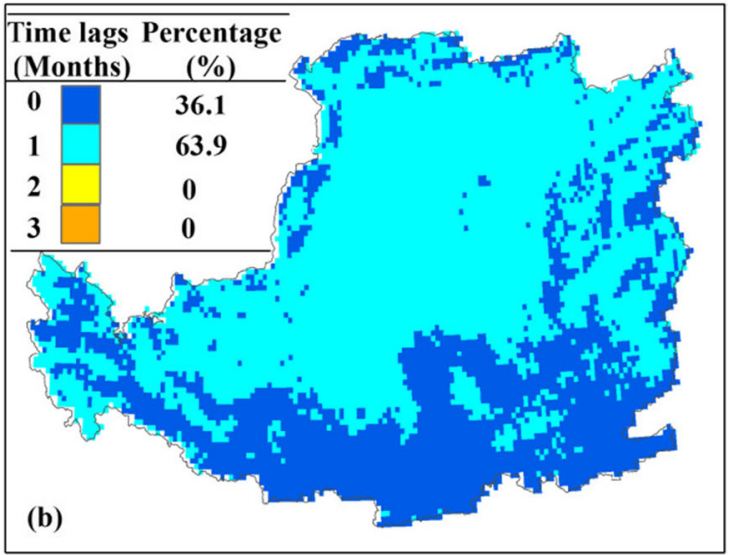

8c) shows that soil erosion has been reduced in most areas $(82 \%)$, with worsening erosion present in only a few areas $(18 \%)$. This is consistent with the spatial variation in vegetation on the Loess Plateau described above (Fig. S4). Interestingly, the regions with the highest degree of improvement correspond to the regions that suffered the greatest degree of erosion. This is especially true in the hilly and gully parts of the Plateau, which are the main source of sediment in the Yellow River (Xin et al. 2015; Zhang et al. 2012a, b).

To better understand the effects of vegetation coverage on erosion, long-term data on the sediment load at the Tongguan and Huayuankou stations were evaluated for different soil conservation periods (Fig. 9). Overall, between 1982 and 2013, there was a downward trend in the average annual sediment load at both Tongguan and Huyuankou stations. A significant reduction in sediment load was detected during this period, which could reflect increased vegetation coverage. Our calculation shows that sediment load at Tongguan station was negatively correlated with vegetation coverage and had a correlation coefficient of -0.49 , which is significant at the 95\% confidence level. The results are consistent with those of Xin et al. (2015), who estimated that vegetation restoration contributed about $2.35 \times 10^{8} \mathrm{t} \mathrm{year}^{-1}$ of the sediment yield decrease in the middle Yellow River.

\section{Discussion}

The restoration of vegetation cover plays a significant role in the control of soil erosion within an ecosystem (Kou et al. 2016). Evidence indicates that re-vegetation is currently a major measure in use for the control of soil erosion on the Loess Plateau (Chen et al. 2007; Nearing et al. 2005; Wen et al. 2010). Afforestation, the return of cropland to grass, and prohibition of grazing are popular re-vegetation measures on the Loess Plateau (Zhao et al. 2013). However, the majority of afforestation projects have been unsuccessful. The newly planted trees and grasses usually grow well for the first few 

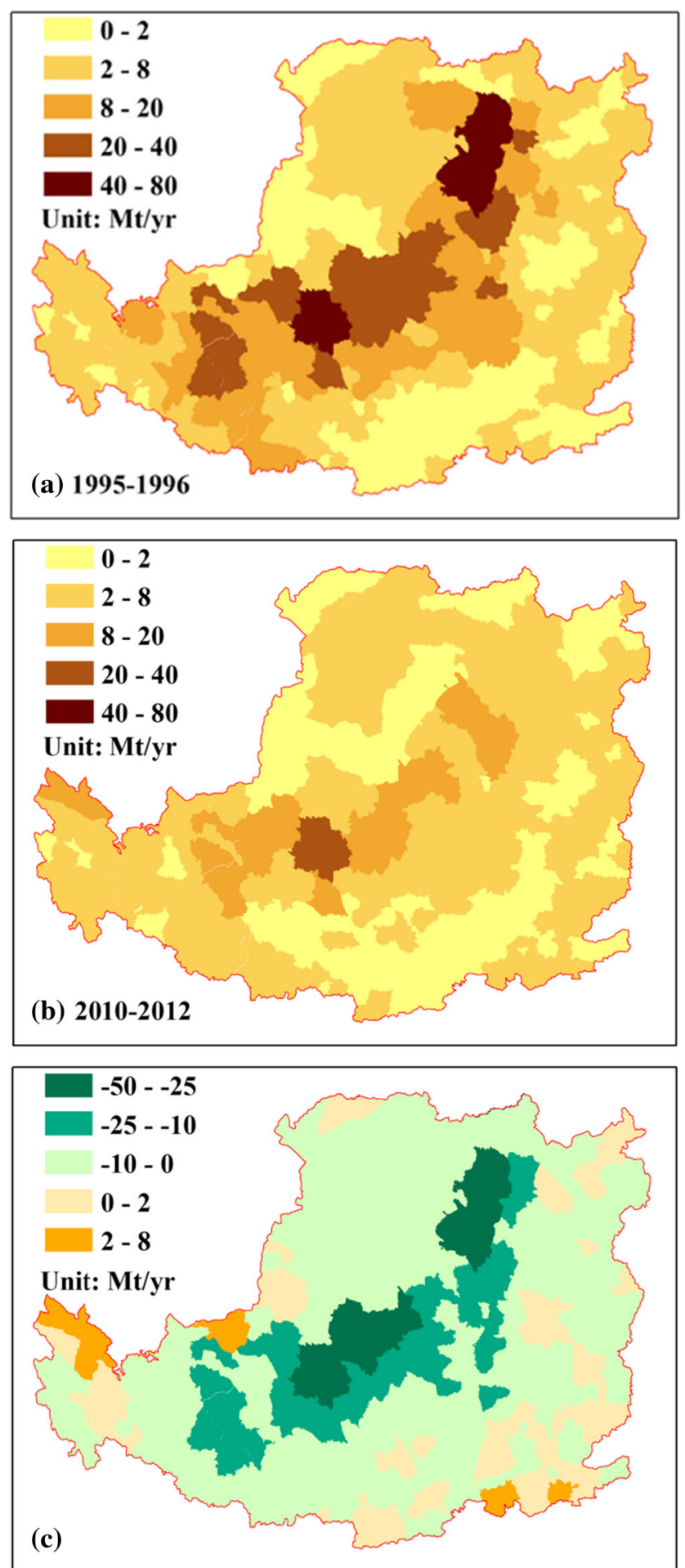

Fig. 8 Spatial distribution of water erosion on the Loess Plateau according to national surveys in 1995-1996 (a) and 2010-2012 (b). The difference in total soil removal between the two surveys (c)

years but then die because of the formation of a dry layer. It has been reported that decreased soil moisture in the afforestation plot, combined with reduced sunlight under the tree canopies, has decreased vegetation cover by $30.5 \%$ in

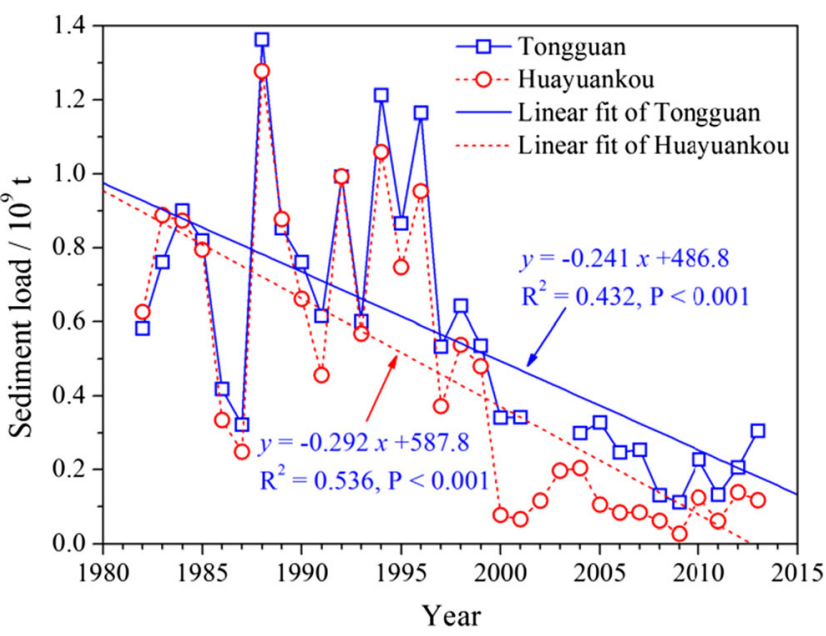

Fig. 9 Annual sediment load at Tongguan and Huayuankou hydrological stations over the period 1982-2013

afforestation plots in arid and semi-arid regions of northern Shaanxi Province (Cao et al. 2009).

Too much emphasis was placed on the economic benefits of afforestation during its initial implementation, leading to a large proportion of non-natural forest with weak ecological functions (Zhang and Liu 2007). Several programs in the Grain-to-Green project, such as in Wuqi County in northern Shaanxi Province, have demonstrated success with natural revegetation, which is now considered the most suitable method for the control of soil erosion and ecological restoration (König et al. 2014; Kou et al. 2016; Sun et al. 2014). However, the process of natural restoration is slow, and engineering measures that promote natural restoration (e.g., artificial irrigation) are also required ( $\mathrm{Li}$ et al. 2015). Although a series of projects that aim to return sloping arable land to forest have been implemented, many of these ecological restoration projects that were based on artificial tree planting have failed, demonstrating the lack of practical support for this method. Afforestation may initially increase the vegetation cover, but it has a negative effect on biodiversity, and its ability to restore the eco-environment depends on both the type of revegetation carried out and the local environment (Lamb et al. 2005; Wang et al. 2014). Inappropriate restoration approaches might exacerbate soil moisture deficits and result in serious soil desiccation, and a consequent reduction in vegetation (Wang et al. 2016; Wang et al. 2010b). Thus, the availability of water and other ecological conditions in the local region should be considered before vegetation restoration is initiated. For more efficient ecological restoration on the Loess Plateau, it may be best to implement the more successful policies, such as prohibition of grazing and logging and conversion of unsuitable cultivated sloping land to forest, while maintaining the natural species. In general, the distribution of economic crops, food crops, artificially planted vegetation, and natural vegetation should be reasonably arranged within the regional governance of the Loess Plateau, forming 
a complete landscape and complex ecosystem (Li et al. 2003; Feng et al. 2016).

\section{Conclusions}

In this study, we used a multiyear NDVI dataset from 1982 to 2013 and corresponding climate datasets to analyze the temporal and spatial trends in NDVI on the Loess Plateau, and the relationship to climate change and human activity. The annual average NDVI showed an upward trend across the 32-year study period, especially in the center of the Loess Plateau. We investigated whether the NDVI response lagged behind monthly changes in precipitation and temperature. We found that vegetation growth had the greatest correlation with precipitation when there was no lag (i.e., within the same month), whereas there was a 1-month lag with temperature. We also quantitatively estimated the relative effects of climate change and human activities on variations in NDVI after correcting for the time-lag effect. Our results show that the contribution of human activities to variations in NDVI has become more significant. For the period 2001-2013, the overall contribution from human activities $(30.4 \%)$ was significantly greater than the contribution during the period 1991-2000 (2.7\%), indicating that the recent restoration measures are more effective than previous measures. Thus, the previous ineffective measures should be canceled to avoid wasting human and financial resources. The increased vegetation coverage has reduced soil erosion on the Loess Plateau, leading in turn to a reduction in the volume of sediment delivered to the lower reaches of the Yellow River. We suggest that natural vegetation restoration is the most effective measure for control of erosion, and engineering measures that promote this should feature in the future governance of the Loess Plateau. A better match of vegetation species and planting density to the natural environment should be considered.

Acknowledgements This research was supported by the National Key Research and Development Program of China (No. 2016YFC0501604) and the National Natural Science Foundation of China (No. 41622101, No. 91547118).

\section{References}

Allen LH, Boote KJ, Jones JW, Jones PH, Valle RR, Acock B, Rogers HH, Dahlman RC (1987) Response of vegetation to rising carbon dioxide: photosynthesis, biomass, and seed yield of soybean. Glob Biogeochem Cycles 1:1-14. https://doi.org/10.1029/ GB001i001p00001

Anderson LO, Malhi Y, Aragao LEOC, Ladle R, Arai E, Barbier N, Phillips O (2010) Remote sensing detection of droughts in Amazonian forest canopies. New Phytol 187:733-750. https://doi. org/10.1111/j.1469-8137.2010.03355.x
Cantón Y, Domingo F, Solé-Benet A, Puigdefábregas C (2001) Hydrological and erosion response of a badlands system in semiarid SE Spain. J Hydrol 252:65-84. https://doi.org/10.1016/S00221694(01)00450-4

Cao SX, Chen L, Yu XX (2009) Impact of China's Grain for Green Project on the landscape of vulnerable arid and semi-arid agricultural regions: a case study in northern Shaanxi Province. J Appl Ecol 46:536-543. https://doi.org/10.1111/j.1365-2664.2008.01605.x

Chapin FS, Sturm M, Serreze MC, McFadden JP, Key JR, Lloyd AH, McGuire AD, Rupp TS, Lynch AH, Schimel JP (2005) Role of landsurface changes in Arctic summer warming. Science 310:657-660. https://doi.org/10.1126/science.1117368

Chen LD, Wei W, Fu BJ, Lü YH (2007) Soil and water conservation on the Loess Plateau in China: review and perspective. Prog Phys Geogr 31:389-403. https://doi.org/10.1177/0309133307081290

Chen T, de Jeu RAM, Liu YY, van der Werf GR, Dolman AJ (2014) Using satellite based soil moisture to quantify the water driven variability in NDVI: a case study over mainland Australia. Remote Sens Environ 140:330-338. https://doi.org/10.1016/j.rse.2013.08. 022

Dekker SC, Rietkerk M, Bierkens MF (2007) Coupling microscale vegetation-soil water and macroscale vegetation-precipitation feedbacks in semiarid ecosystems. Glob Chang Biol 13:671-678. https://doi.org/10.1111/j.1365-2486.2007.01327.x

Fan X, Ma ZG, Yang Q, Han YH, Rezaul M, Zheng ZY (2015a) Land use/land cover changes and regional climate over the Loess Plateau during 2001-2009. Part I: observational evidence. Clim Chang 129: 427-440. https://doi.org/10.1007/s10584-014-1069-4

Fan X, Ma ZG, Yang Q, Han YH, Rezaul M (2015b) Land use/land cover changes and regional climate over the Loess Plateau during 20012009. Part II: interrelationship from observations. Clim Chang 129: 441-455. https://doi.org/10.1007/s10584-014-1068-5

Feng XM, Fu BJ, Piao SL, Wang S, Philippe C, Zeng ZZ, Lü YH, Zeng Y, Li Y, Jiang XH, Wu BF (2016) Revegetation in China's Loess Plateau is approaching sustainable water resource limits. Nat Clim Chang 6:1019-1022. https://doi.org/10.1038/nclimate3092

Fensholt R, Proud SR (2012) Evaluation of earth observation based global long term vegetation trends - comparing GIMMS and MODIS global NDVI time series. Remote Sens Environ 119:131-147. https://doi.org/10.1016/j.rse.2011.12.015

Fu BJ, Liu Y, Lü YH, He CS, Zeng Y, Wu BF (2011) Assessing the soil erosion control service of ecosystems change in the Loess Plateau of China. Ecol Complex 8:284-293. https://doi.org/10.1016/j.ecocom. 2011.07.003

Fu BJ, Wang S, Liu Y, Liu JB, Liang W, Miao CY (2017) Hydrogeomorphic ecosystem responses to natural and anthropogenic changes in the loess plateau of China. Annu Rev Earth Planet Sci 45:223-243. https://doi.org/10.1146/annurev-earth-063016-020552

Gao GY, Ma Y, Fu BJ (2016) Temporal variations of flow-sediment relationships in a highly erodible catchment of the loess plateau, China. Land Degrad Dev 27:758-772. https://doi.org/10.1002/ldr. 2455

Gao P, Mu XM, Wang F, Li R (2011) Changes in streamflow and sediment discharge and the response to human activities in the middle reaches of the Yellow River. Hydrol Earth Syst Sci 15:1-10. https:// doi.org/10.5194/hess-15-1-2011

Gerten D, Schaphoff S, Haberlandt U, Lucht W, Sitch S (2004) Terrestrial vegetation and water balance - hydrological evaluation of a dynamic global vegetation model. J Hydrol 286:249-270. https://doi.org/ 10.1016/j.jhydrol.2003.09.029

Holben BN (1986) Characteristics of maximum-value composite images from temporal AVHRR data. Int J Remote Sens 7:1417-1434. https://doi.org/10.1080/01431168608948945

König HJ, Zhen L, Helming K, Uthes S, Yang L, Cao X, Wiggering H (2014) Assessing the impact of the sloping land conversion 
programme on rural sustainability in Guyuan, Western China. Land Degrad Dev 25:385-396. https://doi.org/10.1002/ldr.2164

Kong DX, Miao CY, Borthwick AG, Duan QY, Liu H, Sun QH, Ye AZ, Di ZH, Gong W (2015) Evolution of the Yellow River Delta and its relationship with runoff and sediment load from 1983 to 2011. J Hydrol 520:157-167. https://doi.org/10.1016/j.jhydrol.2014.09.038

Kong DX, Miao CY, Wu JW, Duan QY (2016) Impact assessment of climate change and human activities on net runoff in the Yellow River Basin from 1951 to 2012. Ecol Eng 91:566-573. https://doi. org/10.1016/j.ecoleng.2016.02.023

Kou M, Jiao JY, Yin QL, Wang N, Wang ZJ, Li YJ, Yu WJ, Wei YH, Yan FC, Cao BT (2016) Successional trajectory over 10 years of vegetation restoration of abandoned slope croplands in the hill-gully region of the loess plateau. Land Degrad Dev 27:919-932. https:// doi.org/10.1002/ldr.2356

Lamb D, Erskine PD, Parrotta JA (2005) Restoration of degraded tropical forest landscapes. Science 310:1628-1632. https://doi.org/10.1126/ science. 1111773

Lantican MA, Guerra LC, Bhuiyan SI (2003) Impacts of soil erosion in the upper Manupali watershed on irrigated lowlands in the Philippines. Paddy Water Environ 1:19-26. https://doi.org/10. 1007/s10333-002-0004-x

Levis S, Foley JA, Pollard D (2000) Large-scale vegetation feedbacks on a doubled CO2 climate. J Clim 13:1313-1325. https://doi.org/10. 1175/1520-0442(2000)013<1313:LSVFOA >2.0.CO;2

Li FM, Xu JX, Sun GJ (2003) Restoration of degraded ecosystems and development of water harvesting ecological agriculture in the semiarid Loess Plateau of China. Acta Ecological Sinica 23:1901-1909 (in Chinese)

Li JJ, Li Z, Lü Z (2016) Analysis of spatiotemporal variations in land use on the Loess Plateau of China during 1986-2010. Environ Earth Sci 75:1-12. https://doi.org/10.1007/s12665-016-5807-y

Li JJ, Peng SZ, Li Z (2017) Detecting and attributing vegetation changes on China's Loess Plateau. Agric For Meteorol 247:260-270. https:// doi.org/10.1016/j.agrformet.2017.08.005

Li SS, Yan JP, Liu XY, Wan J (2013) Response of vegetation restoration to climate change and human activities in Shaanxi-Gansu-Ningxia region. J Geogr Sci 23:98-112. https://doi.org/10.1007/s11442-0130996-8

Li XR, Jin Z, Zhang XB, Zhou WJ (2015) Analysis of ecosystem management of the Loess Plateau during the past 60 years and suggestions for the future development. J Earth Environ 6:248-254 (in Chinese)

Li Z, Liu WZ, Zhang XC, Zheng FL (2010) Assessing the site-specific impacts of climate change on hydrology, soil erosion and crop yields in the Loess Plateau of China. Clim Chang 105:223-242. https://doi. org/10.1007/s10584-010-9875-9

Li Z, Zheng FL, Liu WZ, Jiang DJ (2012) Spatially downscaling GCMs outputs to project changes in extreme precipitation and temperature events on the Loess Plateau of China during the 21st century. Glob Planet Chang 82-83:65-73. https://doi.org/10.1016/j.gloplacha. 2011.11.008

Liang W, Bai D, Wang FY, Fu BJ, Yan JP, Wang S, Yang YT, Long D, Feng MQ (2015) Quantifying the impacts of climate change and ecological restoration on streamflow changes based on a Budyko hydrological model in China's Loess Plateau. Water Resour Res 51: 6500-6519. https://doi.org/10.1002/2014WR016589

Liu W, Sang T (2013) Potential productivity of theMiscanthusenergy crop in the Loess Plateau of China under climate change. Environ Res Lett 8:044003. https://doi.org/10.1088/1748-9326/8/4/044003

Ludwig JA, Wilcox BP, Breshears DD, Tongway DJ, Imeson AC (2005) Vegetation patches and runoff-erosion as interacting ecohydrological processes in semiarid landscapes. Ecology 86: 288-297. https://doi.org/10.1890/03-0569

Mann HB (1945) Nonparametric tests against trend. Econometrica: J Econ Soc 13:245-259
Marques M, Bienes R, Pérez-Rodríguez R, Jiménez L (2008) Soil degradation in central Spain due to sheet water erosion by low-intensity rainfall events. Earth Surf Process Landf 33:414-423. https://doi. org/10.1002/esp.1564

McVicar TR, Van Niel TG, Li LT, Hutchinson MF, Mu XM, Liu ZH (2007) Spatially distributing monthly reference evapotranspiration and pan evaporation considering topographic influences. J Hydrol 338:196-220. https://doi.org/10.1016/j.jhydrol.2007.02.018

Miao CY, Kong DX, Wu JW, Duan QY (2016) Functional degradation of the water-sediment regulation scheme in the lower Yellow River: spatial and temporal analyses. Sci Total Environ 551:16-22. https:// doi.org/10.1016/j.scitotenv.2016.02.006

Miao CY, Ni JR, Borthwick AGL, Yang L (2011) A preliminary estimate of human and natural contributions to the changes in water discharge and sediment load in the Yellow River. Glob Planet Chang 76:196205. https://doi.org/10.1016/j.gloplacha.2011.01.008

Mohsin T, Gough WA (2010) Trend analysis of long-term temperature time series in the Greater Toronto Area (GTA). Theor Appl Climatol 101:311-327. https://doi.org/10.1007/s00704-009-0214-x

Nearing M, Jetten V, Baffaut C, Cerdan O, Couturier A, Hernandez M, Le Bissonnais Y, Nichols MH, Nunes JP, Renschler CS (2005) Modeling response of soil erosion and runoff to changes in precipitation and cover. Catena 61:131-154. https://doi.org/10.1016/j. catena.2005.03.007

Önöz B, Bayazit M (2003) The power of statistical tests for trend detection. Turk J Eng Environ Sci 27:247-251

Ouyang W, Hao FH, Skidmore AK, Toxopeus AG (2010) Soil erosion and sediment yield and their relationships with vegetation cover in upper stream of the Yellow River. Sci Total Environ 409:396-403. https://doi.org/10.1016/j.scitotenv.2010.10.020

Ouyang W, Wang XL, Hao FH, Srinivasan R (2009) Temporal-spatial dynamics of vegetation variation on non-point source nutrient pollution. Ecol Model 220:2702-2713. https://doi.org/10.1016/j. ecolmodel.2009.06.039

Partal T, Kahya E (2006) Trend analysis in Turkish precipitation data. Hydrol Process 20:2011-2026. https://doi.org/10.1002/hyp.5993

Pimentel D, Kounang N (1998) Ecology of soil erosion in ecosystems. Ecosystems 1:416-426. https://doi.org/10.1007/s100219900035

Sayemuzzaman M, Jha MK, Mekonnen A (2014) Spatio-temporal longterm (1950-2009) temperature trend analysis in North Carolina, United States. Theor Appl Climatol 120:159-171. https://oi.org/ 10.1007/s00704-014-1147-6

Scheffer M, Holmgren M, Brovkin V, Claussen M (2005) Synergy between small-and large-scale feedbacks of vegetation on the water cycle. Glob Chang Biol 11:1003-1012. https://doi.org/10.1111/j. 1365-2486.2005.00962.x

Sen PK (1968) Estimates of the regression coefficient based on Kendall's tau. J Am Stat Assoc 63:1379-1389

Shi H, Shao MG (2000) Soil and water loss from the Loess Plateau in China. J Arid Environ 45:9-20. https://doi.org/10.1006/jare.1999. 0618

Sun WY, Shao QQ, Liu JY, Zhai J (2014) Assessing the effects of land use and topography on soil erosion on the Loess Plateau in China. Catena 121:151-163. https://doi.org/10.1016/j.catena.2014.05.009

Sun WY, Song XY, Mu XM, Gao P, Wang F, Zhao GJ (2015) Spatiotemporal vegetation cover variations associated with climate change and ecological restoration in the Loess Plateau. Agric For Meteorol 209:87-99. https://doi.org/10.1016/j.agrformet.2015.05. 002

Tabari H, Somee BS, Zadeh MR (2011) Testing for long-term trends in climatic variables in Iran. Atmos Res 100:132-140. https://doi.org/ 10.1016/j.atmosres.2011.01.005

Tang KL, Zhang P, Wang B (1991) Soil erosion and eco-environment changes in quaternary. Quat Res 4:49-56

Tang LH, Yang DW, Hu HP, Gao B (2011) Detecting the effect of landuse change on streamflow, sediment and nutrient losses by 
distributed hydrological simulation. J Hydrol 409:172-182. https:// doi.org/10.1016/j.jhydrol.2011.08.015

Troch PA, Martinez GF, Pauwels V, Durcik M, Sivapalan M, Harman C, Brooks PD, Gupta H, Huxman T (2009) Climate and vegetation water use efficiency at catchment scales. Hydrol Process 23:24092414. https://doi.org/10.1002/hyp.7358

Tucker C, Pinzon J, Brown M, Slayback D, Pak E, Mahoney R, Vermote E, El Saleous N (2005) An extended AVHRR 8-km NDVI dataset compatible with MODIS and SPOT vegetation NDVI data. Int $\mathrm{J}$ Remote Sens 26:4485-4498. https://doi.org/10.1080/ 01431160500168686

Vereecken H, Kollet S, Simmer C (2010) Patterns in soil-vegetationatmosphere systems: monitoring, modeling, and data assimilation. Vadose Zone J 9:821-827. https://doi.org/10.2136/vzj2010.0122

Wang C, Wang S, Fu BJ, Yang L, Li ZS (2016) Soil moisture variations with land use along the precipitation gradient in the north-south transect of the loess plateau. Land Degrad Dev 28:926-935. https://doi.org/10.1002/ldr.2604

Wang F, Mu XM, Li R, Fleskens L, Stringer LC, Ritsema CJ (2015) Coevolution of soil and water conservation policy and humanenvironment linkages in the Yellow River basin since 1949. Sci Total Environ 508:166-177. https://doi.org/10.1016/j.scitotenv. 2014.11.055

Wang N, Jiao JY, Lei D, Chen Y, Wang DL (2014) Effect of rainfall erosion: seedling damage and establishment problems. Land Degrad Dev 25:565-572. https://doi.org/10.1002/ldr.2183

Wang TM, Kou XJ, Xiong YC, Mou P, Wu JG, Ge JP (2010a) Temporal and spatial patterns of NDVI and their relationship to precipitation in the Loess Plateau of China. Int J Remote Sens 31:1943-1958. https://doi.org/10.1080/01431160902929263

Wang YQ, Shao MA, Shao H (2010b) A preliminary investigation of the dynamic characteristics of dried soil layers on the Loess Plateau of China. J Hydrol 381:9-17. https://doi.org/10.1016/j.jhydrol.2009. 09.042

Wen ZM, Lees BG, Jiao F, Lei WN, Shi HJ (2010) Stratified vegetation cover index: a new way to assess vegetation impact on soil erosion. Catena 83:87-93. https://doi.org/10.1016/j.catena.2010.07.006

Wu DH, Zhao X, Liang SL, Zhou T, Huang KC, Tang BJ, Zhao WQ (2015) Time-lag effects of global vegetation responses to climate change. Glob Chang Biol 21:3520-3531. https://doi.org/10.1111/ gcb. 12945

Wu JW, Miao CY, Wang YM, Duan QY, Zhang XM (2017) Contribution analysis of the long-term changes in seasonal runoff on the Loess Plateau, China, using eight Budyko-based methods. J Hydrol 545: 263-275. https://doi.org/10.1016/j.jhydrol.2016.12.050

Xin ZB, Xu JX, Zheng W (2008) Spatiotemporal variations of vegetation cover on the Chinese Loess Plateau (1981-2006): impacts of climate changes and human activities. Sci China Ser D Earth Sci 51:67-78. https://doi.org/10.1007/s11430-007-0137-2

Xin ZB, Yu XX, Lu XX (2011) Factors controlling sediment yield in China's Loess Plateau. Earth Surf Process Landf 36:816-826. https://doi.org/10.1002/esp.2109

Xin ZB, Ran LS, Lu XX (2012) Soil erosion control and sediment load reduction in the loess plateau: policy perspectives. Int J Water Resour Dev 28:325-341. https://doi.org/10.1080/07900627.2012. 668650

Xin ZB, Yu BF, Han YG (2015) Spatiotemporal variations in annual sediment yield from the middle Yellow River, China, 1950-2010. J Hydrol Eng 20:04014090. https://doi.org/10.1061/(ASCE)HE. 1943-5584.0001113
Xu JH, Li XM, Zhang PD, Lin YP (1998) Delimitation of coarse sediment and study on overlap of coarse sediment and sediment abundant areas in the middle Yellow River basin. J Sediment Res 4:3646 (in Chinese)

Yang ZL (2003) A summary on the history and research progress of ecological construction in the Loess Plateau. World For Res 16: 36-40 (in Chinese)

Yi L, Ren ZY, Zhang C, Liu W (2014) Vegetation cover, climate and human activities on the Loess Plateau. Resour Sci 36:166-174 (in Chinese)

Yue S, Pilon P, Cavadias G (2002) Power of the Mann-Kendall and Spearman's rho tests for detecting monotonic trends in hydrological series. J Hydrol 259:254-271. https://doi.org/10.1016/S00221694(01)00594-7

Yue Y, Ni JR, Ciais P, Piao SL, Wang T, Huang MT, Borthwick AGL, Li TH, Wang YC, Chappell A, Van Oost K (2016) Lateral transport of soil carbon and land-atmosphere $\mathrm{CO} 2$ flux induced by water erosion in China. Proc Natl Acad Sci U S A 113:6617-6622. https://doi.org/ $10.1073 /$ pnas. 1523358113

Zeng N, Neelin JD, Lau KM, Tucker CJ (1999) Enhancement of interdecadal climate variability in the Sahel by vegetation interaction. Science 286:1537-1540. https://doi.org/10.1126/science.286. 5444.1537

Zhang BQ, Wu PT, Zhao XN, Wang YB, Gao XD (2012b) Changes in vegetation condition in areas with different gradients (1980-2010) on the Loess Plateau, China. Environ Earth Sci 68:2427-2438. https://doi.org/10.1007/s12665-012-1927-1

Zhang CS, Hu Y, Shi XL (2016) Analysis of spatial-temporal evolution of vegetation cover in loess plateau in recent 33 years based on AVHRR NDVI and MODIS NDVI. J Appl Sci- Electron Inform Eng 34:702-712. https://doi.org/10.3969/j.issn.0255-8297.2016. 06.006 (in Chinese)

Zhang C, Ren ZY, Li XY (2012a) Research on vegetation response to temperature and precipitation in Loess Plateau. Sci Agric Sin 45: 4205-4215 (in Chinese)

Zhang WH, Liu GB (2007) Review on vegetation restoration in Loess Plateau. Scientia Silvae Sinicae 43:102-106. https://doi.org/10. 11707/j.1001-7488.20070117

Zhang XP, Zhang L, Zhao J, Rustomji P, Hairsine P (2008) Responses of streamflow to changes in climate and land use/cover in the Loess Plateau, China. Water Resour Res 44:W00A07. https://doi.org/10. 1029/2007WR006711

Zhao GJ, Mu XM, Jiao JY, An ZF, Klik A, Wang F, Jiao F, Yue XL, Gao P, Sun WY (2016) Evidence and causes of spatiotemporal changes in runoff and sediment yield on the chinese loess plateau. Land Degrad Dev 28:579-590. https://doi.org/10.1002/ldr.2534

Zhao GJ, Mu XM, Wen Z, Wang F, Gao P (2013) Soil erosion, conservation, and eco-environment changes in the Loess Plateau of China. Land Degrad Dev 24:499-510. https://doi.org/10.1002/ldr.2246

Zheng FL (2006) Effect of vegetation changes on soil erosion on the Loess Plateau. Pedosphere 16:420-427. https://doi.org/10.1016/ S1002-0160(06)60071-4

Zhou ZC, Shangguan ZP, Zhao D (2006) Modeling vegetation coverage and soil erosion in the Loess Plateau area of China. Ecol Model 198: 263-268. https://doi.org/10.1016/j.ecolmodel.2006.04.019

Zhou P, Anbang W, Xinbao Z, Xiubin H (2013) Soil conservation and sustainable eco-environment in the Loess Plateau of China. Environ Earth Sci 68:633-639. https://doi.org/10.1007/s12665-012-1766-0 